\title{
Subtitle in Teaching Pronunciation with Video
}

\author{
RokiRanjaniSanjadireja, rokiranjani@gmail.com, UniversitasPendidikan Indonesia, Bandung, \\ Indonesia
}

\begin{abstract}
Video has been a tool to improve learning outcomes, but many teachers do not apply the correct procedure in using video as the medium of teaching pronunciation. Pronunciation should have taken its fascination into classroom teaching-learning. This research's objective is to test the use of video subtitles in teaching pronunciation and its impact on students' pronunciation. This research is a quantitative study with the design of a true experiment posttest only. One group watches non subtitled video, and the other watches captioned the video. The researcher has found that watching videos only, with subtitles or no subtitles, does not improve students' pronunciation. It suggested that teachers may have to do another activity such as enhancement, repetition, or scaling in teaching pronunciation rather than watching only.
\end{abstract}

Keywords: audio-visual, subtitle, teaching pronunciation, video

\section{INTRODUCTION}

Teaching pronunciation encounters with rapid technological development. The technology enhances learning(Arjuna I. Ranasinghe \& Diane Leisher, 2009). Technology, like a visual aid, opens the opportunity to a new approach in teaching that provides a stimulus that has a vital capacity to sustain learner's attention(Celce-Murcia et al., 1996). Generally speaking, the school syllabus rarely mentions video as a teaching pronunciation tool in English teaching. The focus on the four language skills has led pronunciation into bias due to losing media in education. It is also problematic because the moment students hear language from a native that is becoming unfamiliar due to little amount of training in pronouncing English. The practice should enable the learner to consolidate language on another aspect of its use like the intonation and pronunciation(Ira Pratiwi, 2013).

Integrating pronunciation and listening has been proposed by many teachers to teach pronunciation. Teaching pronunciation through listening to the audio, as the medium, exhilarates joyous and comfortable atmosphere that smooth learning in delicate pronunciation area (Ebong \& Marta J. Sabbadini, 2016). Pronunciation is as a pivotal element of language learning has also been a missing piece and an abandoned aspect in teaching English as a Foreign Language (Haycraft, 1978). Students who learn English as a Foreign Language (EFL) often mispronounce words due to the differences nature of English sound and their first language(Haycraft, 1978). The student feels insecure, trying pronunciation as they speak heard by other people(Muyskens, 1994).

One factor that influences students' confidence in pronunciation practice is the embarrassing experience when they make mispronunciation on a particular word. They are afraid of making mistakes(M.Mustafa, 2014). Tanveer(2007) pointed out pronunciation as a source of anxiety. Besides, he believes that pronunciation skills improvement requires listening practice. Thus, the amount of time devoted to listening to native language causes low authentic experience. It may lead to loss of opportunity in practicing target language and resulting in a lower level of pronunciation(Tanveer, 2007). Teachers should analyze students' pronunciation problems to construct lessons regarding English phonological systems and students' needs, and

67 | IJET| Volume. 9, Issue 1. July 2020

Copyright 2020 RokiRanjaniSanjadireja is licensed under Creative Commons Atrribution-ShareAlike 4.0 International License. 
then decide what to practice immediately (Ahmad Yani, 2012).

Video is also one of the most common tools to teach pronunciation. Perhaps one of the most influential visual books is from Cooper et al. (1991). This ground-breaking book introduced how to implement the principle of active watching rather than just passively watching a video. The paper stated answer listening comprehension questions. The students should drag into a much more active engagement(K.D Xerry, 2017)

New London Group coined 'multiliteracies' in the mid-1990s, a group of scholars that argue literacy pedagogy, supposed to be interconnected to the rapidly changing cultural, technological, and social environment. They say that the book was the dominant medium of communication for a century. Otherwise, with the rapid growth of a technologically evolving landscape and the ascendance of the image, especially the moving image, the screen has taken that place (Gunther Kress \& Theo Van Leeuwen, 2006).

Moreover, regarding those issues, subtitle in a video helps students learn from a visual aid. Subtitle can improve students'understanding because it provides an opportunity for numerous quantities of comprehensible and authentic language input (Robert Vanderplank, 1988). Using subtitles in teaching through media is supposedly under specific rules of usage (Merry, 2015). However, many teachers do not know the rules for consideration of using such a medium. The video usage needs follow up activity after watching activity; even subtitle has less impact on learning in teaching the second language without the action after(M.S Merry et al., 2016).

Subtitle benefits beginner students to adjust their capability to save sound memory. Subtitle impacts students' learning by providing clear direction and understanding of a broader meaning in a video (Robert Vanderplank, 1988). Subtitle in the video is acting as scaffolding. Scaffolding provides the guideline by the teacher to control elements that are beyond the child's capabilities(Emi Emilia, 2005). Scaffolding proposed to describe how children can perform complex tasks with the help of a knowledgeable adult, which otherwise they would be incapable of doing. Provision prepared when the student needs it to reach competencies in more effective ways. In other words, they are scaffolded at the point they need it. Even more, the teacher must be responsive to the needs of the students. The teacher has to be ready in serving the guideline at the time it is needed (Wells, 1999)

Mukherjee and Roy (2003) found that the use of visual tools to contextualize spoken speech led the students to $30 \%$ more understanding. It goes in line with Canning-Wilson's (2000) research with a statement that emphasizes visual that enhances the meaning of the message conveyed by the speakers. When a graphic is explained by subtitles in audio, learning new information is faster than the words presented in a text-only medium(Clark \& Lyons, 2004). One effective way to assure this immediacy of meaning is by the help of subtitles. Canning-Wilson (2000) supported the benefit of subtitles in teaching English. He argued that the images contextualized reinforced language learning so that the learner can comprehend the meaning in terms of vocabulary recognition.

English multimedia, like a song or online video, can be used for a wide variety of EFL learning and teaching activities, particularly in helping students' awareness of how the way English is produced (Ebong \& Marta J. Sabbadini, 2016). Wilson (2001) mentioned the use of visual images in foreign and second language classroom enhance the use of target language. Audio media provides a sound that stimulates students' listening practice. Native speaking 
audio helps the students improve their pronunciation by imitating authentic pronunciation. Students pronounce English utterances almost correctly close to native pronunciation by imitating from what spoken in audio (Adela, 2017).

Some viewers have considered subtitles as a nuisance. By some argument, traditionally believed that subtitles or captions are disturbing and the cause of feeling laziness(Zanon, 2006). Despite, the use of subtitle does not disturb nor distract the student from learning the language. Instead, it benefits students with the low-level skill of listening(Robert Vanderplank, 1988).In addition to the merit potential of subtitled video in learning the second language, it is necessary to be aware of the impact of visual associations on memory and the mnemonic power of imagery(Danan, 1992).

There are noted benefits of using subtitles in language learning(Zanon, 2006). The user can connect the gap in reading and listening. 2) Language learning the foreign can be achieved rapidly by trying to keep up with the subtitles in the dialogues. 3) Learning how to pronounce many words is acquired consciously and unconsciously during the interaction. 4) It is following the plot in subtitles is easy. 5) Recognition skills also developed at the same time. 6) It reinforces the understanding of English context-bound expressions from captions in the visual display. Thus, it helps learners acquire new feelings. 7) Understanding humor would be more comfortable with the help of the captions. It is difficult, but it is also rewarding the language classroom(Lonergan, 1989). Subtitles enhance the massage, increasing the enjoyable character of the activity. 8) Captions increase students' focus. 9) Finally, subtitles motivate students to study outside the classroom context, especially from watching TV and cinema, listening to the original dialogues, etc.

It is acceptable that most of the language teachers agree the use of visuals aids can enhance language teaching. It is because visual aids help teachers to present real-world situations into the classroom where that makes learning a lot meaningful and exciting (Brinton, 2008). Mannan (2005) points out the merit of visual aids in the language classroom by stating that visual aids help the teacher to establish, clarify, connect and coordinate contextually accurate that makes interpretations and appreciations more practical, concrete, engaging, motivating, and meaningful.

The same statement, also stated by Canning-Wilson (2000) explicitly by his speech that describes visual display, can help students interpret an immediate meaning in the language. It benefits the student and teacher by clarifying the message. These advantages suggest that visual help make a task or situation more authentic (Christine Canning-Wilson, 2000). The other benefit of using visual aids mentioned by researchers(Kemp \& Dayton, 1985). They claim visuals aid preserves in motivation and maintaining attention by adding variety and making the learning more engaging(Katherine Bradshaw, 2003). Further, visuals can help raise the readers' interest, curiosity, and motivation (Richard E. Mayer \& Roxana Moreno, 1998).

This research is to answer the use of video for teaching pronunciation - the study of the use of subtitles in teaching pronunciation conducted at the novice level. The external factors that influence pronunciation like background knowledge, motivation, family tree, reading habit, listening habit, speaking practice, and others will not be discussed in this paper unless it is related to the finding. The research answers whether students internalize meaning or pronunciation the most in the video with instruction of paying attention to pronunciation. For further implementation, the teacher can use this research in teaching pronunciation. The teacher can decide whether the subtitle should show or not. There are things to do and not to do in 
pronunciation teaching, especially in the connection to using audio-visual multimedia.

Therefore, the research question for this research intended to find out the use of subtitles in teaching pronunciation.

1. Does watching subtitled video improve the students' pronunciation? And how significant was the impact?

2. How do the students perceive learning with the subtitled video?

\section{METHOD}

The research started with an assumption that subtitles might help students in learning a second language in building their understanding from watching clips, video, or film. But did it affect pronunciation too? Departing from that issue, the researcher tried to conduct his research by involving a novice level of language proficiency - the research site located in a junior high school at Sumedang. The samples were grade $8^{\text {th }}$ ranging from 13-15 years old with Indonesian as their mother tongue. This research was a quantitative study. The group divided into control and experiment. Class VIII B would be the experimental group, whereas class VIII D would be the control group. This model is known as a quasi-experimental design(Sugiyono, 2010).

This research meant to answer these following questions:

1. Does watching subtitled video improve the students' pronunciation? And how significant was the impact?

2. How do the students perceive learning with the subtitled video?

The result of the instrument would be tested in several statistics measurements to find the significance level of the research. Because the data was less than 50 normality tests with Shapiro, Wilk would conduct to see the data distribution result so the further analysis could be determined. The hypotheses were:

H0: the population normally distributed.

H1: the data did not normally distribute.

Then the two means in control and experiment was tested in further whether parametric or non-parametric test. The procedure meant to answer the first research question. The test hypotheses would state as follow:

1. If Sig. (2-tailed) score $<0.05$, then there is a significant difference between the control group and the experimental group.

2. If Sig. (2-tailed) score $>0.05$, then there is no significant difference between the control group and the experimental group.

The calculation would use SPSS software. The probability $(\mathrm{P})$ of this test is 0.05 or $5 \%$.

Copyright 2020 Rd \begin{tabular}{|l|l|l|}
\hline $\begin{array}{l}\text { Normality test } \\
\text { (Shapiro Wilk) }\end{array}$ & censed & $\begin{array}{l}\text { Parametric (t-test) or } \\
\text { Non-parametric test } \\
\text { (Mann-Whitney test) }\end{array}$ \\
(Msue 1. July 2020 \\
ion-ShareAlike 4.0 \\
ernational License.
\end{tabular}


The sample of the research divided into two groups consisting of 20 students for each group. The total subjects were 40 students - data collection collected by providing treatment in two different groups. Group determination was chosen equally in class VIII B and VIII D. The equivalent grade ensured the same level of language proficiency. The data collection conducted in a junior high school located at St. SimpangHauragombong, Pamulihan, Jawa Barat, Indonesia.

The instruments of this research were the pronunciation of oral tests and interviews. The pronunciation test items were displayed on card pieces to the students one by one to test their pronunciation after watching a video. The words, phrases, and sentences test items based on the video 91-Year-Old Grandma Guesses Pokemon Names (see appendix).

Before running the pronunciation test, the students guided to watch 5 minutes video. The video is accessible at www.youtube.com entitled 91-Year-Old Grandma Guesses Pokemon Names. The video's difficulty level reviewed through matching with students' experience in the Indonesia English syllabus of the revised version 2017. The vocabulary used in the video was fundamental. The words commonly used in daily conversation, and it checked on the corpus that the words were widely expressed frequently in the native language. Based on the syllabus also, the student should have studied the words and expressions in the previous grade.

Although written word frequency (Francis \& Kucera, 1982)constituted a popular measure of word familiarity, which was highly predictive of word recognition, the researcher used spoken the only database from corpus to analyze the frequency level of test items. The test was conducted objectively without intermixing the researcher's belief and assumption onto writing to find out the precise result of research.

Interview around teaching-learning conducted for building an argument on finding and discussion as additional data and underlying assumptions. A few students were interviewed personally after doing pronunciation test to find out their background knowledge about English. They would interview in their mother tongue. The questions asked the learner's background and their perception around the video as follow:

1. What's your difficulty in learning pronunciation from the subtitled video?

2. Are you familiar with watching the English subtitled video?

3. Do you prefer the video with subtitles or not? Why?

4. What do you think about the video duration?

5. Does the subtitle help your pronunciation improved?

The data collection of the research came from the control and experiment group:

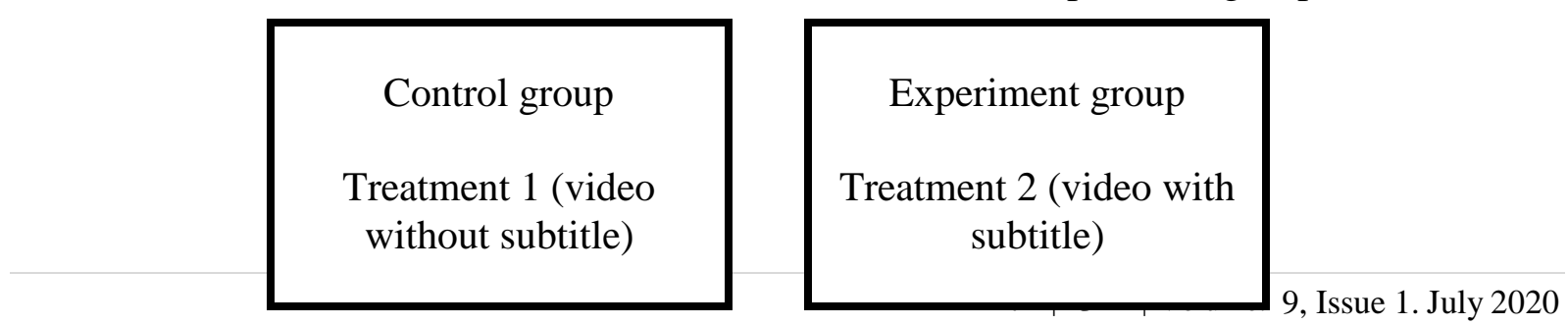

Copyright 2020 RokiRanjaniSanjadireja is licensed under Creative Commons Atrribution-ShareAlike 4.0 International License. 
The study was to measure subjects' pronunciation in the level of word, phrase, and sentence with these steps:

1. The students had clear instructions about the video we were going to watch. They were allowed to take notes, mumble, or do any strategy to remember pronunciation as much as they could.

2. Samples watched five minutes humorous video entitled 91-Year-Old Grandma Guesses Pokemon Names.

3. Then after watching the video, the pronunciation was measured by doing oral pronunciation checks. The measurement test took from the expression on video. The test instrument conducted to measure ability, knowledge, or performance(Brown, 2004). The researcher then showed some words, phrases, sentences from the video watched. The test consisted of 5 items: words, phrases, and penalties (see: appendix). The details of the trial were analyzed through word frequency in the corpus before running the test to see frequency usage of the words in the native speaking language as additional data.

After collecting the data, an analysis conducted using SPSS software version 16. The collected data from the oral test would be scored into an interval number from 1 to 5 inserted in the software - data analysis conducted by comparing two means in the control and experiment group with T-Test. The result would be described further and analyzed based on related theories and sequence of events on the field.

Alpha of the research is 0.05 or $5 \%$ in two-tailed design with null hypothesis statement as follow:

Ho $=$ There is no significant difference between the control group and the experimental group.

The scoring instrument and the rubric used in this research appended in the enclosure. The data copied into a table with three scoring divisions: words, phrases, and sentences. 


\section{RESULTS}

A normality test conducted to see if the two groups equal. This procedure was the preparation to ensure that the students had an equivalent level of English proficiency. This research expected to have a normal distribution, which means that one group had no difference compared to the other group. Normal distribution was considered essential since the comparison between the two groups would be described quantitatively.

The result of the normality test displays as follows:

Table III.I. Normality Test Table

\begin{tabular}{|l|r|r|r|r|r|r|}
\hline & \multicolumn{3}{|c|}{ Kolmogorov-Smirnov $^{\mathrm{a}}$} & \multicolumn{3}{c|}{ Shapiro-Wilk } \\
\cline { 2 - 7 } & Statistic & \multicolumn{1}{c|}{ df } & \multicolumn{1}{c|}{ Sig. } & Statistic & \multicolumn{1}{c|}{ df } & \multicolumn{1}{c|}{ Sig. } \\
\hline Control & .239 & 20 & .004 & .915 & 20 & .081 \\
Experiment & .173 & 20 & .118 & .931 & 20 & .161 \\
\hline
\end{tabular}

As seen in the table, the significant values both in the control and experiment groups are 0.081 and 0.161 . The data distribution of the groups is higher than zero point zero five (>0.05). It means the data has a normal distribution in both the control and experiment groups. $\mathrm{H} 0$ rejected, $\mathrm{H} 1$ accepted.

Then, after conducting the treatment, the researcher tested the students with the pronunciation test to measure their pronunciation by the words, phrases, and sentences produced after watching the video. The control group watched the video without subtitles, and the experimental group watched the video with subtitles.

Here is the mean table of the control and experimental group from oral pronunciation test from the students in SMPN 1 Pamulihan:

Table III.II. Mean Table

\begin{tabular}{|l|l|l|l|}
\hline & Word & Phrase & Sentence \\
\hline Control group mean & 1.65 & 1.85 & 1.6 \\
\hline Experiment group mean & 1.65 & 1.95 & 1.7 \\
\hline
\end{tabular}

Score interval 1 to 5

The students also have a problem with necessary English communication because they hardly ever had speaking practice to deal with. Most of English teaching-learning in a class conducted by reading and writing. Speaking and listening were the least held in teaching and learning.

As shown in table III, II, the control group got a slightly better result in phrase and sentence by margin difference at 0.1 . It seems that the treatment almost does not affect 
the students' progress, virtually no improvement. Then, the researcher did the statistic calculation by comparing the two means in the t-test. The result of the SPSS calculation, the significance of the two ways, was 0.634. It means that there was no significant difference between the treatment in the control and experimental group. The t-test table displays as follow:

Table III.III. T-test table

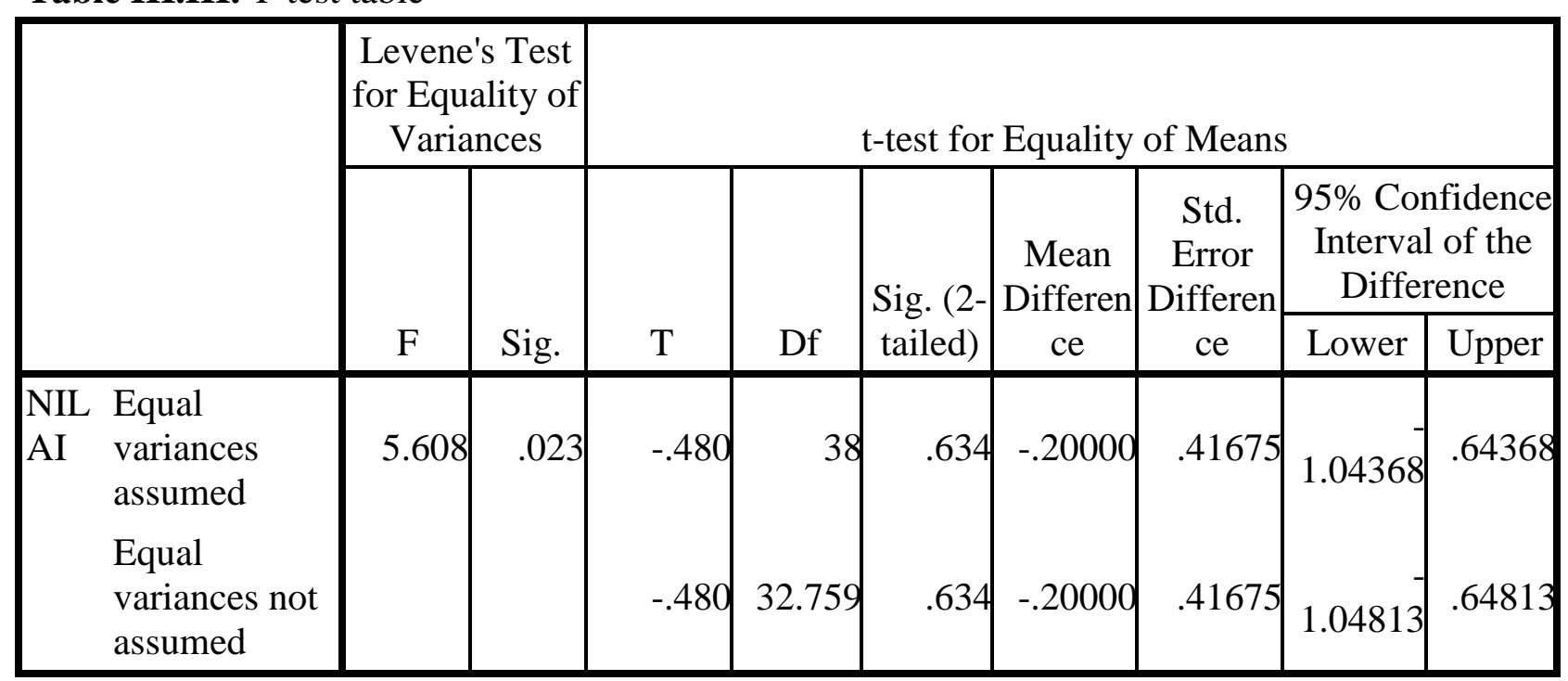

From the data collected, the discussion to answer the first research question is as follow:

1. The video does not affect much on the improvement of student's pronunciation. As seen in the table, the development only raises 0.1 from the control group mean, almost does not affect. 0.634 significant value, which is more than 0.05 shows that control and experiment group result has no significance between means. Instead, many students confidently said that they could understand better when watching videos with subtitles. It could mean that the footage tended to improve understanding rather than pronunciation. Even the instruction before the test had emphasized recognition of articulation, and students were still focusing on interpreting the intention of moving images rather than the pronunciation.

2. Several factors influence pronunciation improvement directly, like speaking practice and perhaps drilling. It goes along with Doff's(1990) statement that said repetition on drilling is useful to get students familiar with a specific structure or formulaic expression.

Based on the interview, students prefer watching videos with subtitles without subtitles. Most of them are satisfied, actively interacted with visual content, and enjoy learning. Some of the students may experience flow during watching videos as they were attracted to the video. In other words, visual aids like subtitles had acknowledged as a powerful tool in learning a second language.

At some stage of learning second language development, as mentioned by Zanon(2006), the use of subtitles or captions should be removed gradually because of feeling safe and confident. It recommended combining the use of caption or subtitle with 
viewing without it or other activity that makes students independently capable without the support of caption or subtitle. Little by little, the aids can be removed like Bruner's scaffolding theory until the students are entirely able to stand by themselves.

Overall, the students said that they received a positive experience with the video. As the researcher stood to observe learning, the students were also able to concentrate on the video. The students also liked the duration of the video, which they mentioned not too short and not too long. It was five minutes humorous video with the topic they had been familiar with.

They did not find it difficult learning with video's subtitled. In contrast with the no improvement of the pronunciation, the students may feel learning was fun. Though, it may improve in other areas of English, such as vocabulary and contextual understanding. However, this research is not a conclusion that said learning with subtitles will not improve pronunciation. Long term research may be leading to a different outcome, and advanced school with technology-based learning is also interesting to dig.

1. Level of engagement. In teaching pronunciation with video, engagement is necessary to improve students' level of participation. The engagement is to promote students to be proactive in participating in the learning process. A passive environment does not significantly improve student's ability to speak in, which will influence their pronunciation too. When talking about the engagement, the approach necessarily took action. A suitable approach to make a different outcome, to draw not only attention but also participation, is required.

2. They are learning background. Based on the interview, many of the teaching processes conducted in three languages: Indonesia, English, and Sudanese. As mentioned in the literature review, listening influences a student's pronunciation(Tanveer, 2007). It highly recommended using the target language in language teaching-learning. Some students might find it difficult to follow the lesson for the first time, but it will be beneficial for the long run.

3. Familiarity with technology. The visual tool is a potent tool to learn the language (Arjuna I. Ranasinghe \& Diane Leisher, 2009). Unfortunately, many teachers, even they are aware of the potential, they do not make the use of technology to support learning. In the interview section, the researcher found that the English teacher at that school had never used a projector for teaching nor the speaker for supporting listening practice. At this rate, students will fail to understand spoken English conducted by a native speaker whose pronunciation is authentic.

4. Learning approach. The model of education with the lack of exposure can waste critical age for learning pronunciation. Passing a significant period seems to affect pronunciation's mastery (Lanneberg, 1964). Children imitate what spoken in audio(Adela, 2017). Pronunciation acquisition and children development of second language occupying advantages (Cameron, 2001). By providing the right method, students at a young age have a high potential to learn a second language better in the perfection of pronunciation. 


\section{CONCLUSION}

This research has concluded that watching videos only does not improve students' pronunciation significantly at the novice level. Instead, students focus on interpreting meaning even though the instruction was clear enough to pay attention to pronunciation. Therefore, the use of other techniques like drilling might be beneficial in internalizing pronunciation after watching. Follow up activity after watching visual aid is the key to learning pronunciation in the classroom. The instructional task given like to speak, pronounce, identify (orally), read, mime and say, chant, say together, discuss, present will implicitly improve student pronunciation.

The video played both with subtitle and without subtitle and both in control and experiment group does not improve student pronunciation. The researcher tends to correlate five principles of listening by Harmer that are related to what students will gain during learning. One of the principles stated that only watching is not enough. Students need multiple times to construct and obstruct pronunciation information.

Watching a video does both with subtitle and without subtitle, and both in control and experiment group does not improve students' pronunciation. But enhancement does the task.

For the novice level, it recommended getting used to visual display. Theoretically described by many researchers, subtitles, or captions can help students extract learning information - the subtitle built as learning to scaffold. But eventually, the scaffold should be lessened until the student can independently pronounce without visual aids.

Although the video gain students' attention and their impression were also attracted, however, it is not enough to only play the video for once. It could mean the need to follow up activity to enhance the students' learning. The implication of the finding suggests that watching tasks, whether in online education or offline learning, should be prepared with the enhancement activity. Thus, it indicates that watching alone does not provide significant improvement in students' pronunciation ability.

Five principles behind teaching listening by Harmer(2007)with modification to the video must be taken into consideration when doing teaching pronunciation. Principle one and two already carried out during the research, but the outcome is still not significant. The result must be different if teaching is associated with all five principles bellow, especially when teaching pronunciation through audio-visual:

Principle 1: The audio is just a medium. Not what makes learning happens.

Principle 2: Using digital tools requires preparation.

Principle 3: Once time played, the video will not be enough. A further enhancement is required.

There is almost no improvement when a teacher plays the video only once. Students might need to play it again to pick up the things they missed. The first time often used just to give students an idea of what the pronunciation material sounds. 
Principle 4: Responding to the content is necessary, not just passively listen or read.

Along with reading subtitles, the teacher could provide practice to draw out the pronunciation. Meanwhile, teaching how the sound produced like phonics also encourages students to actively watching rather than passively listening.

Principle 5: Different listening tasks for the different listening stage.

The teacher needs to set different tasks that follow up listening in various stages. Example: for the first listening, the task needs to be reasonably straightforward so that the students can improve their general understanding and response. In the next stage, however, we may focus on the detail of information language use like pronunciation.

In addition to the five principles, students' scaffolding by using subtitles removed until the student can independently produce the right pronunciation in English.

Still, in the EFL context, linguistic factors such as lack of vocabulary, grammatical, and pronunciation also become the source of student's problem for being reluctant to participate in the class. The other study suggested by Smith (2011) in Juhana (2011)for students who encounter difficulty in learning a second language to do these tips: taking non-formal classes, using mass media, practicing, joining conversation club, and joining toastmaster international. Philosophically spoken, if we do something, there might be improvement or reduction. But speaking, if we do nothing, there will be an absolute degradation. 


\section{REFERENCES}

Adela. (2017). The influence of Using Audio-Visual Media towards Students' Pronunciation Mastery. Indonesia: Institut Agama Islam Negeri Raden Intan Lampung.

Ahmad Yani. (2012). Teachers' Incorrect Pronunciation and Its Impact on Young Learners: (A Review on Linguistic Aspects of EFL Classroom Practices). TEYLIN 2: From Policy to Classroom.

Arjuna I. Ranasinghe, \& Diane Leisher. (2009). The Benefit of Integrating Technology into The Classroom. Department of Mathematics, Alabama A \& MUniversity.

Brinton, L. J. (2008). The comment clause in English: Syntactic origins and pragmatic development (Studies in the English Language). Cambridge University Press.

Cameron, L. (2001). Teaching Languages to Young Learners. Ernst Klett Sprachen: Cambridge University Press.

Celce-Murcia, Celce-Murcia, M., Brinton, D. M., \& Goodwin, J. M. (1996). Teaching Pronunciation: A Reference for Teachers of English to Speakers of Other Languages. New York: Cambridge University Press.

Christine Canning-Wilson. (2000). Practical Aspects of Using Video in the Foreign Language Classroom. Abu Dhabi: The Center of Excellence for Research and Training.

Clark, R. ., \& Lyons, C. (2004). Graphics for Learning: Proven Guidelines for Planning, Designing, and Evaluating Visuals in Training Materials. California: Pfeiffer.

Danan, M. (1992). Reversed subtitling and dual coding theory: New directions for foreign language instruction. Houghton, Michigan: Language Learning.

Deb Roy, \& Niloy Mukherjee. (2004). Towards situated speech understanding: visual context priming of language models. Ames Street, Cambridge: ELSEVIER,Computer Speech and Language.

Doff, A. (1990). Teach English: A Training Course for Teachers. Cambridge University: British Council.

Ebong, B., \& Marta J. Sabbadini. (2016). Developing pronunciation through songs. TeachingEnglish|BritishCouncil|BBC.https://www.teachingenglish.org.uk/article/devel oping-pronunciation-through-songs

Emi Emilia. (2005). A Critical Genre-Based Approach To Teaching Academic Writing In A Tertiary EFL Context In Indonesia. Melbourne: Department of Language, Literacy and Arts Education Faculty of Education The University of Melbourne.

Francis, W. ., \& Kucera, H. (1982). Frequency Analysis of English Usage. Houghton Mifflin: Oxford University Press.

Gavin T. L. Brown. (2004). Teachers' conceptions of assessment: implications for policy and professional development, Assessment in Education: Principles, Policy \& Practice. Routledge. https://doi.org/10.1080/0969594042000304609

Gunther Kress, \& Theo Van Leeuwen. (2006). Reading Images: The Grammar of Visual Design. Routledge.

Harmer, J. (2007). How to Teach English. Edinburg: Pearson Longman.

Haycraft. (1978). An Introduction to English Language Teaching. London: Longman.

Ira Pratiwi. (2013). Improving The Speaking Skill Through Communicative Activities of The Eighth Grade Students of MTsN 1 Mlati in The Academic Year of 2012/2013. Yogyakarta State University Press.

Juhana. (2011). Investigation the Difficulties Encountered by Students in Practicing Speaking in English Class. Indonesia: Universitas Pendidikan Indonesia.

Katherine Bradshaw. (2003). Coin-Operated Machines Change Single Copy Sales. Green State University: Newspaper Research Journal.

K.D Xerry. (2017). The Image in English Teaching. University of College London: Guttenberg

78 | IJET| Volume. 9, Issue 1. July 2020 Copyright 2020 RokiRanjaniSanjadireja is licensed under Creative Commons Atrribution-ShareAlike 4.0 International License. 
Press.

Kemp, J. ., \& Dayton, D. (1985). Planning \& producing instructional media (5th ed.). Harper \& Row, Publishers.

Lanneberg. (1964). A biological perspective of language. In E. H. Lenneberg (Ed.), New directions in the study of language. MIT Press.

Lonergan, B. (1989). Les voies d'une théologie méthodique: Ecrits théologiques choisis. Revue thomiste.

M.Mustafa. (2014). Penang Matriculation College Students' Opinions on the Use of Online Forums. Forum Komunikasi Mahasiswa.

M.S Merry, M Van Houtte, \& O Agirdag. (2016). Teachers' Understanding of Multicultural Education and the Correlates of Multicultural Content Integration in Flanders. Education and Urban Society.

Muyskens. (1994). Priorities for Intermediate-Level Language Instruction. The Modern Language Journal.

R Cooper, M Lavery, \& M Rinvolucri. (n.d.). Video. Oxford: Oxford University Press. Richard E. Mayer, \& Roxana Moreno. (1998). A Split-Attention Effect in Multimedia Learning: Evidence for Dual Processing Systems in Working Memory. Journal of Educational Psychology.

Robert Vanderplank. (1988). The Value of Teletext Sub-titles in Language Learning. ELT Journal.

Sugiyono. (2010). Metode Penelitian Ilmiah. Indonesia: Alfabeta.

Tanveer, M. (2007). Investigation of the Factors That Cause Language Anxiety for ESL/EFL Learners in Learning Speaking Skills and the Influence It Casts on Communication in the Target Language. Glasgow University.

Vissa, U. (1994). Teaching a unit of educational psychology to B.Ed. Students. Islamabad, Pakistan: The Progress of Education.

Wells, G. (1999). Dialogic Inquiry: Towards a Sociocultural Practice and Theory of Education. Cambridge University Press.

Zanon, N. (2006). Using Subtitle to Enhance Foreign Language Learning. Universidad Nacional de Educación a Distancia: Porta Linguarum. 


\section{TESTING ITEM}

\begin{tabular}{|c|c|c|}
\hline PRONUNCIATION & PHONEMES & IN VIDEO \\
\hline TEST & & TIMING \\
\hline \multicolumn{3}{|l|}{ Word } \\
\hline Animal & 'ænIməl & 00.04 \\
\hline Strawberry & 'stro:bəri & $00.11^{\prime}$ \\
\hline Newspaper & ‘nju:zpeipə & 02.09' \\
\hline Unusual & ^n'ju:Зひəl & $02.26^{\prime}$ \\
\hline Pieces & 'pi:sIz & 03.06 \\
\hline \multicolumn{3}{|l|}{ Phrase } \\
\hline Battle people & 'bætl 'pi: pl & $00.33^{\prime}$ \\
\hline Beautiful animal & ‘bju:təfひl 'ænIməl & 00.38 \\
\hline Very important & ‘vعriIm'pว:tənt & 01.38 \\
\hline Big tail & bIgteIl & $02.51^{\prime}$ \\
\hline Blast water & bla:st'wว:tə & $03.27^{\prime}$ \\
\hline Sentence & & \\
\hline You tell me & ju:tहlmi: & $00.13^{\prime}$ \\
\hline $\begin{array}{l}\text { What's so funny about } \\
\text { that? }\end{array}$ & wDtssəU & 01.19' \\
\hline You're ridiculous & 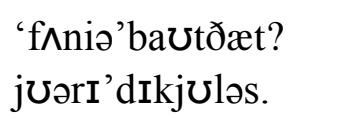 & 01.58 \\
\hline What's your name? & wDtsjว:neIm? & $02.54^{\prime}$ \\
\hline Two pairs of arms & tu:peəzbva:mz & $03.14^{\prime}$ \\
\hline
\end{tabular}




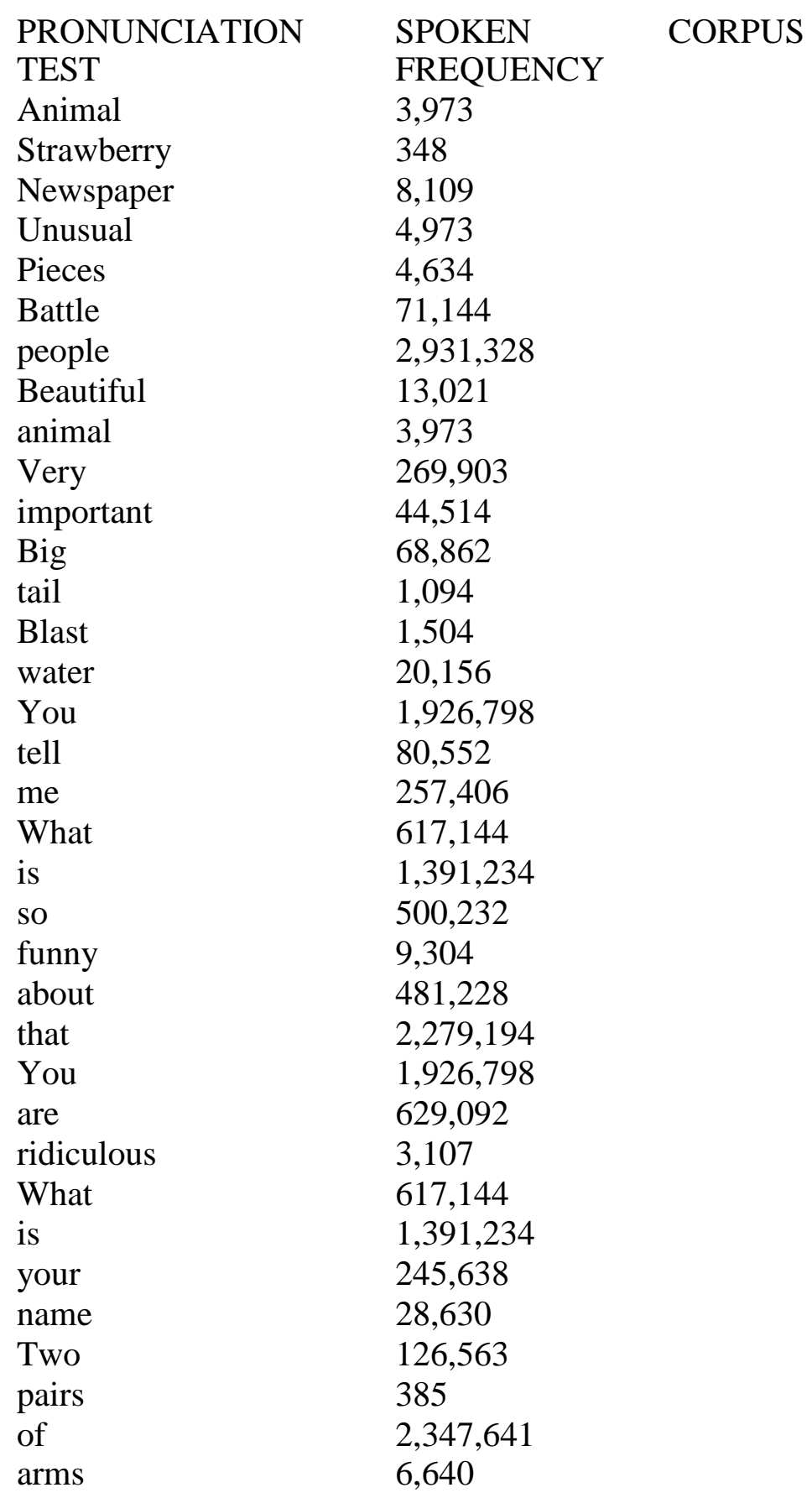


PRONUNCIATION

Errors in pronunciation are frequent but can understand by a native speaker used to deal with foreigners attempting to speak his language.

The accent is intelligible though often quite faulty. Bad

\author{
LIKERT SCALE RUBRIC SCORE \\ Very bad 1 \\ Unable to be \\ understood.
}

Mistakes in
pronunciation
make word/
phrase/ sentence
hardly recognized.

Average

Understandable, but stress and intonation is not incorrect order

Good

Understandable.

Very little error in stress and intonation.

Very good

Understandable. The stress, intonation is well pronounced.

\section{SCORING TABLE I}

SMPN 1 PAMULIHAN

Jl. SimpangHauragombong, Kec. Pamulihan (022) 7914184

GRADE VIII D (CONTROL GROUP)

$\begin{array}{lllll}\text { NO } & \text { NAME } & \text { WORD } & \text { PHRASE } & \text { SENTENCE } \\ 1 & \text { Ai } & 2 & 1 & 2 \\ 2 & \text { Akbar } & 1 & 1 & 2 \\ 3 & \text { Aldi } & 2 & 1 & 2 \\ 4 & \text { Arif } & 2 & 2 & 2\end{array}$




$\begin{array}{lllll}5 & \text { Dea } & 1 & 2 & 1 \\ 6 & \text { Dewi } & 2 & 2 & 1 \\ 7 & \text { Dina } & 3 & 2 & 2 \\ 8 & \text { Evi } & 3 & 2 & 1 \\ 9 & \text { Feby } & 2 & 2 & 1 \\ 10 & \text { Gilar } & 2 & 2 & 2 \\ 11 & \text { Hanusa } & 1 & 2 & 2 \\ 12 & \text { Ilyas } & 2 & 2 & 2 \\ 13 & \text { Karina } & 1 & 1 & 1 \\ 14 & \text { Kiki } & 1 & 2 & 1 \\ 15 & \text { Maya } & 1 & 2 & 2 \\ 16 & \text { Peni } & 2 & 2 & 1 \\ 17 & \text { Ridwan } & 2 & 3 & 2 \\ 18 & \text { Sendi } & 1 & 2 & 1 \\ 19 & \text { Siti } & 1 & 2 & 2 \\ 20 & \text { Yosep } & 1 & 2 & 2 \\ & \text { Total } & 33 & 37 & 32 \\ & \text { Mean } & 1.65 & 1.85 & 1.6\end{array}$


SCORING TABLE II

SMPN 1 PAMULIHAN

Jl. SimpangHauragombong, Kec. Pamulihan (022) 7914184

GRADE VIII B (EXPERIMENT GROUP)

$\begin{array}{lllll}\text { NO } & \text { NAME } & \text { WORD } & \text { PHRASE } & \text { SENTENCE } \\ 1 & \text { Addia } & 3 & 3 & 2 \\ 2 & \text { Anisa } & 1 & 1 & 1 \\ 3 & \text { Chandra } & 1 & 2 & 1 \\ 4 & \text { Ilham } & 2 & 2 & 2 \\ 5 & \text { Ismi } & 1 & 2 & 3 \\ 6 & \text { Kamilah } & 2 & 2 & 2 \\ 7 & \text { Kristina } & 3 & 2 & 1 \\ 8 & \text { Messa } & 1 & 1 & 1 \\ 9 & \text { Mia } & 1 & 2 & 1 \\ 10 & \text { M Ridwan } & 2 & 3 & 2 \\ 11 & \text { NengEvi } & 1 & 1 & 2 \\ 12 & \text { Novi } & 1 & 1 & 2 \\ 13 & \text { Risfa } & 1 & 1 & 1 \\ 14 & \text { Risma } & 1 & 2 & 2 \\ 15 & \text { Sindi } & 2 & 2 & 2 \\ 16 & \text { Sri Ayu } & 3 & 3 & 1 \\ 17 & \text { Wandi } & 2 & 2 & 2 \\ 18 & \text { Winda } & 2 & 2 & 1 \\ 19 & \text { Wisnu } & 2 & 3 & 3 \\ 20 & \text { Yayan } & 1 & 2 & 2 \\ & \text { Total } & 33 & 39 & 34 \\ & \text { Mean } & 1.65 & 1.95 & 1.7\end{array}$


TEST ITEMS INSTRUMENT
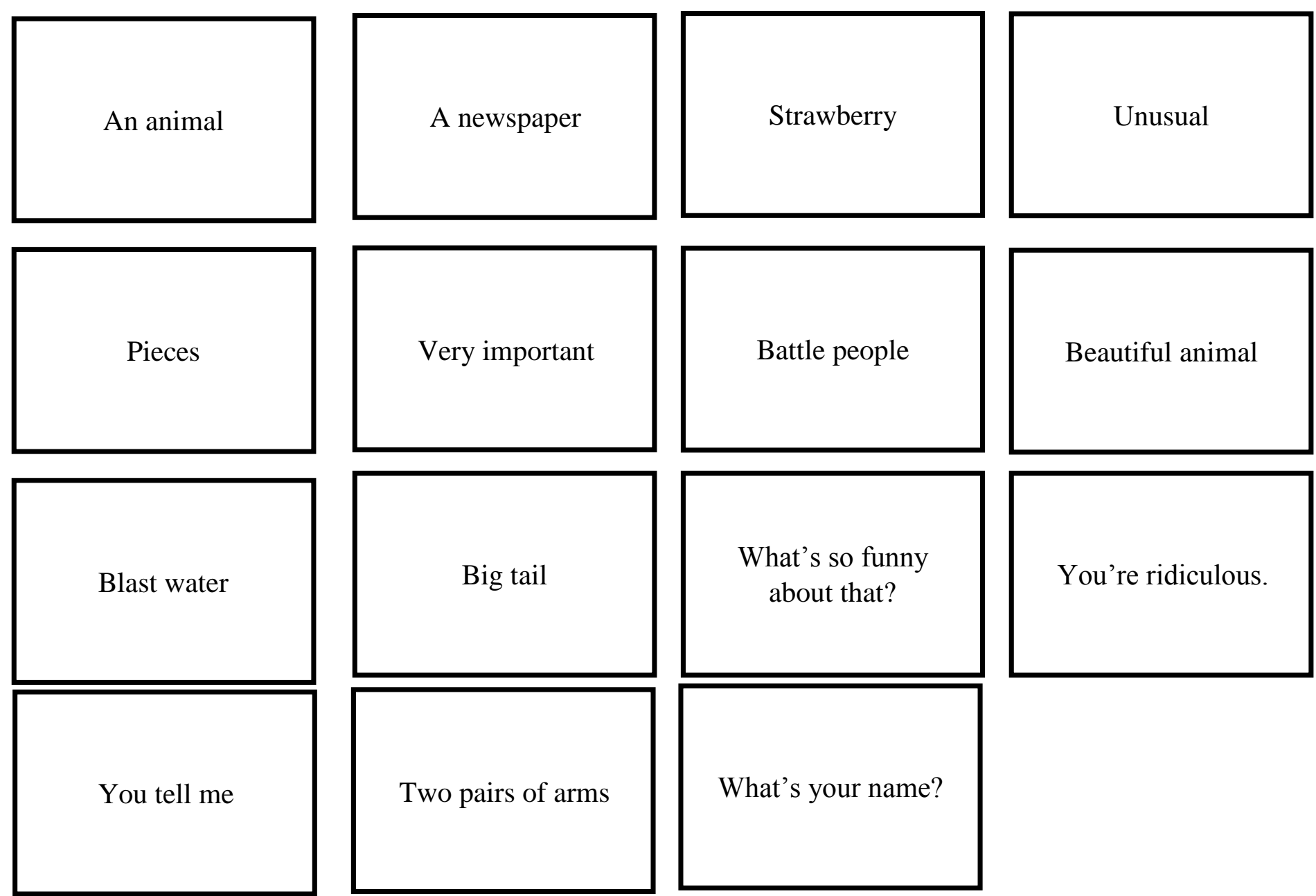

You tell me

Two pairs of arms

What's your name? 